\begin{tabular}{|c|c|c|}
\hline \multirow{3}{*}{$\begin{array}{l}\text { EREM 74/3 } \\
\text { Journal of Environmental Research, } \\
\text { Engineering and Management } \\
\text { Vol. } 74 \text { / No. } 3 \text { / } 2018 \\
\text { pp. } 55-63 \\
\text { Dol 10.5755/j01.erem.74.3.21521 } \\
\text { @ Kaunas University of Technology }\end{array}$} & \multicolumn{2}{|c|}{$\begin{array}{c}\text { Eastern Podilia as a Structural Unit of a Pan-European } \\
\text { Environmental Network }\end{array}$} \\
\hline & Received 2017/12 & Accepted after revision 2018/09 \\
\hline & \multicolumn{2}{|c|}{ crossef http://dx.doi.org/10.5755/j01.erem.74.3.21521 } \\
\hline
\end{tabular}

\title{
Eastern Podilia as a Structural Unit of a Pan-European Environmental Network
}

\section{O.V. Mudrak}

Communal Higher Educational Institution (CHEI) 'Vinnytsia Academy of Continuing Education', Hrushevskogo str. 13, Vinnytsia, 21100, Ukraine

\section{Yu. Yu. Ovchynnykova}

Vasyl' Stus Donetsk National University, 600-richcha str., 21, Vinnytsia, 21021, Ukraine

\section{G. V. Mudrak}

Vinnytsia National Agrarian University, Soniachna 3, Vinnytsia, 21008, Ukraine

\section{M. Nagorniuk}

Communal Higher Educational Institution (CHEI) 'Vinnytsia Academy of Continuing Education', Hrushevskogo str. 13, Vinnytsia, 21100, Ukraine

\section{Corresponding author: ov_mudrak@ukr.net}

O.V. Mudrak, Communal Higher Educational Institution (CHEI) 'Vinnytsia Academy of Continuing Education', Ukraine

Based on scientific, methodological and practical principles and approaches, the scheme of Eastern Podilia ecological network, which forms a part of the pan-European ecological network, was developed. Different types of its structural elements, such as key, connecting, buffer and rehabilitating territories were distinguished, their geographic confinement, area and status were determined. Typical plant groups, which are the basis for formation of biogeocenotic cover of the key territories (biocentres), were defined. The results of the research show that the ecological network of the region is formed by 24 key, 16 connecting and 60 rehabilitating territories. Currently, the number and area of buffer zones that are established around key and connecting territories is being clarified. The total area of structural elements of the ecological network of Eastern Podilia (key, connecting and rehabilitating territories) is $884,087.53 \mathrm{ha}$, which makes $33.37 \%$ of the total area of the region. It should be noted that world experience determines the biological balance of territories only if at least $60 \%$ of natural 
ecosystems are present. Therefore, the ecological network of the region still needs substantial improvement and scientifically grounded implementation.

Keywords: biotic and landscape diversity, structural elements of ecological network, natural reserve fund, sustainable development, Eastern Podilia.

\section{Introduction}

Preservation of biotic diversity is one of the most important tasks of the human community for achieving its sustainable development. Biotic diversity matters for all spheres of socioecological and economic activity of people, substantially influencing the formation of their culture of natural management. A human, as a biological species, must realize that its survival depends on the survival of other species, from preserving the entire completeness of the genetic pool in ecosystems and landscapes as a guarantee of maintaining their sustainable correlation. This task was formulated in the documents of the World Ecological Summits, the Action Plan 'Agenda for the XXI Century', the UN Convention 'On Biodiversity' (Mudrak et al., 2015).

The Pan-European Strategy for the Conservation of Biotic and Landscape Diversity (Sofia, 1995), approved by the Ministers of the Environment of 54 countries of Europe, was adopted for pursuance of the Convention on Biodiversity within Europe. According to its recommendations, the Pan-European Ecological Network (PEN) was developed as the only space functional system of European territories with natural or partially altered landscapes. This network has to cover as many different national environmental protection systems as possible. The majority of EU countries have already moved from the strategy of preserving biotic diversity units through their protection to the strategy of creating national ecological networks (NENs), which must meet the requirements of their functioning in the PEN and perform the functions of preserving biotic diversity, sustainable development, and non-exhaustive use of biological resources in economic activity. In Ukraine, this process is only gaining momentum, which is stipulated by a number of obstacles: the emergence of new forms of ownership and large-scale licensing of land, forest and water use (Mudrak et al., 2013; Popovych, 2007).

The main objective of the creation of ecological networks (ENs) is the overall improvement of the environment, the conditions of human activity through the elimination of anthropogenic fragmentation of the biogeocenotic cover, creating its continuity and functional integrity and increasing the ability of the wildlife to self-healing, self-purification and self-regulation. An important task of the EN is to provide a favourable sozological status of representative and unique ecosystems, habitats, species and landscapes.

The EN concept, which uses scientifically-based principles and approaches, allows us to implement an ecosystem approach in the process of functional and spatial analysis of its territory. It will become the basic instrument of the sustainable development on the landscape and ecosystem level only by maintaining such ecological functions as: 1) preservation of a representative set of habitats of species that provide sufficient populations of species (for feeding, distribution of young and adult individuals or for colonisation of other areas of the habitat); 2) providing opportunities for seasonal migrations, genetic exchange between different local populations, their movement from those habitats the conditions of which have deteriorated, as well as for migrations due to global warming; 3 ) protection of the integral nature of vital environmental processes (e.g., floods, ecological successions, etc.); 4) preservation of biotic diversity; 5) stabilisation of ecological balance; 6) increasing the productivity of landscapes; and 7) improvement of the environment and the provision of sustainable development of society (Marynych, 2005).

The basic methodological basis for the practical implementation of NENs, as components of the PEN, should be the principle of preventing fragmentation of ecosystems (landscapes). For this purpose, different levels of EN must be mutually coordinated: local EN with district EN, district EN with provincial EN, provincial EN with regional EN, regional EN with national EN, national EN with European EN, and European EN 
with planetary EN. At present, it is necessary to create a holistic and interrelated natural territorial system of multi-level ecological networks (Mudrak, 2010).

The research objectives are to highlight the main elements of the ecological network of Eastern Podilia, to show its importance as an integral representative structural unit of the pan-European ecological network.

\section{Materials and Methods}

The structural elements of the Eastern Podilia EN such as key territories (KTs) or natural or reference nuclei, connecting territories (ecological corridors, EC), buffer zones (BZs) and rehabilitating territories (RTs) were the object of the study. These elements, in their continuous unity, create the EN that functionally combines the centres of biotic and landscape diversity into a single structural and functional system.

The main methods of research include geobotanical, zoogeographic, hydroecological, landscape-ecological, forest-typological, agroecological, retrospective analyses as well as monitoring, statistical, cartographic and field methods of research.

\section{Results and Discussion}

An ecological network is the only natural territorial system with the purpose to ensure ecosystem integrity, cenotic value, bio landscape representativeness through the combination of territories and objects of the nature reserve fund (NRF), as well as other territories of special value for the protection of the natural environment (NPS), rational nature management, socio-economic benefits for the local population, and to increase the level of environmental safety of the territory (Mudrak et al., 2013).

The problems of preservation and reproduction of biotic and landscape diversity, stabilisation of ecological balance, increase of ecosystem productivity, public health care, improvement of the conditions of life and ensuring a balanced development of society are extremely relevant and important for Eastern Podilia, the natural complex which occupies $4.5 \%$ of the territory of the state located within the most cultivated region - the Right Bank Forest-steppe of Ukraine (Mudrak et al., 2017)
Eastern Podilia is located on the right bank of the Dnipro River within the boundaries of Pridneprovska and Podilska uplands. Compared with other regions, it has the largest number of neighbours (Mudrak et al., 2013). In the west, it borders with Chernivtsi and Khmelnytsky regions, in the north with Zhytomyr region, in the east with Kiev, Kirovograd and Cherkasy regions, and in the south with Odesa region and the Republic of Moldova, including part of the border $(202 \mathrm{~km}$ ) which belongs to the self-proclaimed Pridnestrovian Moldavian Republic. Its length from north to south is $204 \mathrm{~km}$, and from west to east $-196 \mathrm{~km}$. Its area is 26.5 thousand sq. $\mathrm{km}(4.5 \%$ of Ukraine's territory) (Mudrak et al., 2017).

According to geobotanical zoning of the territory of Ukraine (2003), Eastern Podilia lies within the Eurasian steppe region, which belongs to the Holarctic Dominion. It includes the forest-steppe subregion of the Eastern European forest-steppe province of oak forests, steppe meadows and meadow steppes of the Ukrainian forest-steppe subprovince, which comprises the central and northern part of the North Podilsky district of hornbeam-oak and oak forests, steppe meadows and meadow steppes, the north-eastern part of the Northern Right-Bank Pridniprovsky district hornbeam-oak forests, steppe meadows and meadow steppes, the eastern part of the Central Right-Bank Pridniprovsky district of hornbeam-oak, oak forests and meadow steppes, the southern part of the district South Podilia oak forest and meadow steppes and the whole territory Central Podilia hornbeam, oak and beech forests and upland meadows (Didukh et al., 2003).

The territory of Eastern Podilia, according to the physico-geographical zoning of Ukraine (2005), belongs to the Eastern European plain geographic country of the forest-steppe zone. It consists of the Dniester-Dnipro forest-steppe region, which includes confined parts of the north-western and north-eastern Prydniprovska highland region, Central Prydniprovsky and Southern Podilsky forest steppes, and the entire territory of Prydnistrovsky East Podilsky and Srednebuzky forest-steppe (Marynych, 2005).

The structure of the East Podilia EN is represented by various types of territories that perform particular functions, for instance, key, connecting, buffer and rehabilitating territories. KTs ensure the preservation of representative and unique components of the region biotic and landscape diversity. ECs combine KTs, provide the migration of animals and the exchange of 
genetic material. BZs protect KTs and ECs from external influence. RTs provide the formation of the functional and spatial integrity of the EN and recovery to the original natural state (Popovych, 2007).

On the territory of Eastern Podilia, the structural elements of the EN have 4 levels: international, national, regional (interregional) and local. International (transboundary) protected areas (regional landscape parks, covering the area of at least 5,000 ha), which connect the adjacent ENs of the UN countries (Republic of Moldova), serve as the basis for the KT (natural nuclei, bio centres, $\mathrm{BCs}$ ) on the international level. The basis of the $\mathrm{KT}$ on the national level is the $\mathrm{BC}$ of functioning and promising national nature parks (NNPs), with an area of at least 1,000 ha, representing the most unique landscape cenosis and species diversity. Natural nuclei of the regional level are formed on the basis of territories of functioning and prospective nature reserves of national and local importance, protected areas of the regional landscape parks, natural monuments of national importance, with an area of more than 500 ha representing the biotic diversity, unique, typical natural complexes of physico-geographical regions, and districts. Natural nuclei of the local level are located on the territory of functioning and promising wildlife sanctuaries and natural monuments of national and local significance, RLPs, protected tracts, with an area of less than 500 ha representing the biotic diversity and typical natural complexes and groups of landscapes (Mudrak et al., 2013).

On the basis of different approaches, the scheme of the EN of Eastern Podilia was drawn up (Fig. 1).

Fig. 1

Scheme of the ecological network of Eastern Podilia

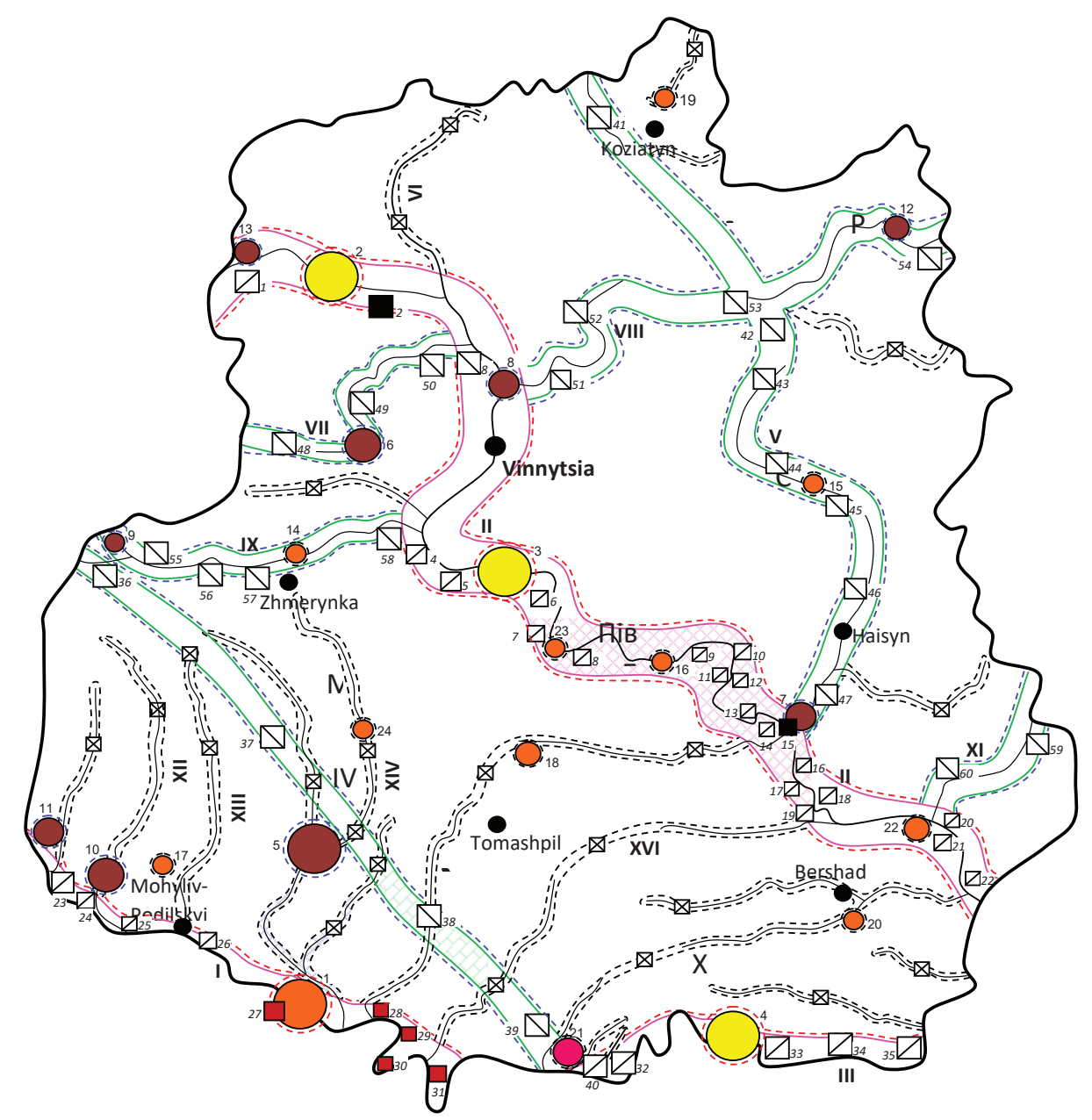


TYPES OF CONNECTING TERRITORIES

$x \times$ - valley river

|ा|س冂) - forest steppe

$\square Z$-forest

ZZX-Tovtry

$\square$-of national level

$\square$-of regional level

$\sum$ - of local level

TYPES OF KEY TERRITORIES

(natural nuclei)

- international

- national

- regional

- local

\section{TYPES OF REHABILITATING TERRITORIES (RTs)}

- RTs are situated within the natural nucleus of international level or national EC

$\square$ - RTs are situated within the natural nucleus of national level or national EC

$\nabla$ - RTs are situated within the natural nucleus of regional level or regional EC

$\bigotimes$ - RTs are situated within the natural nucleus of local level or local EC

- RTs are situated within the promising natural nucleus or promising EC
BUFFER ZONES (width)

$$
\begin{aligned}
& ---500 m \\
& ----100 m \\
& ----50 m
\end{aligned}
$$

AREAS OF KEY TERRITORIES (natural nuclei)

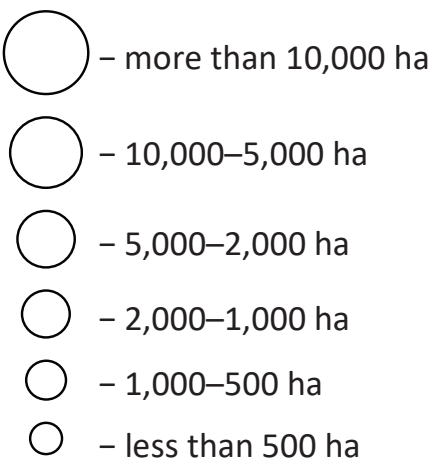

AREAS OF REHABILITATING TERRITORIES (RT)

$\square$ - more than 400 ha

$\square-400-300$ ha

$\square-299-200$ ha

$-199-100$ ha

- less than 100 ha

\section{NAMES OF ECOLOGICAL CORRIDORS}
I. Dnistrovskyi
II. Buzkyi (Pivdenno-Buzkyi)
III. Pivdenno-Podilskyi (Southern Ukrainian)
IV. Murafsko-Tovtrovyi
V. Hnylopyatsko-Sobskyi
VI. Snyvodskyi
VII. Zharskyi
VIII. Desniansko-Roskyi

IX. Rivskyi

X. Dokhnianskyi

XI. Udytskyi

XII. Liadovskyi

XIII. Nemyiskyi

XIV. Murafskyi

XV. Rusavskyi

XVI. Silnytskyi 


\begin{tabular}{|c|c|c|c|c|c|c|}
\hline \multicolumn{7}{|c|}{ Key territories (natural nuclei, biological centres) } \\
\hline № & & Name & \multicolumn{3}{|c|}{ Status in EN } & Area, ha \\
\hline 1 & \multicolumn{2}{|l|}{ Dnisterska } & \multirow{2}{*}{\multicolumn{2}{|c|}{$\begin{array}{l}\text { International } \\
\text { National }\end{array}$}} & & 18,230 \\
\hline 2 & \multicolumn{2}{|l|}{ Tsentralno-Podilska } & & & & 46,420 \\
\hline 3 & \multicolumn{2}{|l|}{ Seredniobuzka } & \multicolumn{3}{|c|}{ National } & 16,730 \\
\hline 4 & \multicolumn{2}{|l|}{ Karmeliukovo-Podilska } & \multicolumn{3}{|c|}{ National } & $15,393.9$ \\
\hline 5 & \multicolumn{2}{|l|}{ Murafska } & \multicolumn{3}{|c|}{ Regional } & $10,068.93$ \\
\hline 6 & \multicolumn{2}{|l|}{ Zharska } & \multicolumn{3}{|c|}{ Regional } & $3,018.7$ \\
\hline 7 & \multicolumn{2}{|l|}{ Buho-Sobska } & \multicolumn{3}{|c|}{ Regional } & 1,503 \\
\hline 8 & Buho-Desnianska & & & Regional & & 1,073 \\
\hline 9 & Harmatska & & & Regional & & 456 \\
\hline 10 & Liadovska & & & Regional & & 3,503 \\
\hline 11 & Naddnistrianska & & & Regional & & $1,229.1$ \\
\hline 12 & Hopchytsko-Nadroska & & & Regional & & 982.2 \\
\hline 13 & Sandratsko-Bereznianska & & & Regional & & 532.4 \\
\hline 14 & Rivska & & & Local & & 346.5 \\
\hline 15 & Illinetsko-Dashivska & & & Local & & 546 \\
\hline 16 & Samchynetska & & & Local & & 218 \\
\hline 17 & Hrabarkivska & & & Local & & 487 \\
\hline 18 & Zhuravlivska & & & Local & & 595 \\
\hline 19 & Sestrynivska & & & Local & & 48 \\
\hline 20 & Ustianska & & & Local & & 173 \\
\hline 21 & Horiachkivsko-Kniahynsk & & & Local & & $1,035.2$ \\
\hline 22 & Krushynivska & & & Local & & 604 \\
\hline 23 & Mazurovetska & & & Local & & 214.3 \\
\hline 24 & Kopystyrynska & & & Local & & 150.7 \\
\hline & & Total & & & & $23,557.93$ \\
\hline & & Connecting territories (natural & logical corrid & idors) & & \\
\hline № & Name & Geographic confinement & Length, km & $\begin{array}{l}\text { Width, } \\
\text { km }\end{array}$ & $\begin{array}{c}\text { Status in } \\
\text { ecological network }\end{array}$ & Area, ha \\
\hline 1 & Dnistrovska & the Dniester River Valley & 166 & $2-4$ & National & 66,421 \\
\hline$\|$ & Buzka & Valley of the Pivdennyi Buh & 352 & $2-8$ & National & 211,232 \\
\hline III & $\begin{array}{l}\text { Pivdenno-Podilska } \\
\text { (Southern Ukrainian) }\end{array}$ & $\begin{array}{l}\text { Balta Plain, valley of the Savranka and } \\
\text { Brytavka }\end{array}$ & 35 & $1-4$ & National & 28,753 \\
\hline IV & Murafsko-Tovtrova & Murafski Tovtry & 140 & $2-6$ & Regional & 57,246 \\
\hline $\mathrm{V}$ & Hnylopyatsko-Sobska & Valleys of the Rivers Hnylopyat and Sob & 176 & $2-4$ & Regional & 52,821 \\
\hline $\mathrm{VI}$ & Snyvodska & the Snyvoda Valley & 58 & $1-3$ & Local & 11,604 \\
\hline VII & Zharska & the Zhar Valley & 75 & $2-6$ & Regional & 30,163 \\
\hline VIII & Desniansko-Roska & Valley of the Desna and Ros & 163 & $1-6$ & Regional & 57,050 \\
\hline IX & Rivska & the Riv Valley & 83 & $1.5-3.5$ & Regional & 20,753 \\
\hline$x$ & Dokhnianska & the Dokhna Valley & 68 & $1-2$ & Local & 10,221 \\
\hline $\mathrm{XI}$ & Udytska & the Udych Valley & 33 & $1-2$ & Regional & 4,952 \\
\hline XII & Liadovska & the Liadova Valley & 88 & $1-3$ & Local & 35,213 \\
\hline XIII & Nemyiska & the Nemyia Valley & 64 & $1-2$ & Local & 9,618 \\
\hline XIV & Murafska & the Murafa Valley & 163 & $1-4$ & Local & 40,753 \\
\hline$X V$ & Rusavska & the Rusava Valley & 78 & $1.5-2.5$ & Local & 31,212 \\
\hline XVI & Silnytska & Valley of the Silnytsia and Vovchytsia & 91 & $1.5-3$ & Local & 20,475 \\
\hline & & Total & & & & 688,487 \\
\hline & Struc & ral elements (KT, EC) $-30.64 \%$ of the tot & rea of the reg & gion & & $812,044.93$ \\
\hline
\end{tabular}


According to the developed scheme, we singled out 24 KT and 16 CT: 1 nucleus of the international level (Dnisterske with an area of 18,230 ha, which includes the designated wetlands (WL) of the international importance 'Valley of the Dniester River' with an area of 5,394 ha, and 3 on the national level (78,543.9 ha), 9 on the regional level (22,366.33 ha), 11 on the local level $(4,417.7$ ha). The total area of KT constitutes 123,557.93 ha, which makes up $4.66 \%$ of the total area of the region. The KT of the national level conclude Tsentralno-Podilske (46,420 ha), Seredniobuzke (16,730 ha), Karmeliukovo-Podilske (15,393.9 ha), the KT of the regional level include Murafske (10,068.93 ha), Zharske (3,018.7 ha), Buho-Sobske (1,503 ha), Buho-Desnianske (1,073 ha), Harmatske (456 ha), Liadovske (3,503 ha), Naddnistrianske (1,229.1 ha), Hopchytsko-Nadroske (982.2 ha), Sandratsko-Bereznianske (532.4 ha), KT of the local level comprise Rivske (346.5 ha), Illinetsko-Dashivske (546 ha), Samchynetske (218 ha), Hrabarkivske (487 ha), Zhuravlivske (595 ha), Sestrynivske (48 ha), Ustianske (173 ha), Horiachkivsko-Kniahynske (1,035.2 ha), Krushynivske (604 ha), Mazurovetske (214.3 ha), Kopystyrynske (150.7 ha).

The connecting territories in Eastern Podilia are 3 CT on the national level: Pivdennopodilskyi (with an area of 211,232 ha, as part of the Buzkyi meridional CT), Dnisterskyi (66,421 ha - Dnisterskyi meridional CT), Pivdennopodilskyi (28,753 ha - Pivdennopodilskyi latitudinal CT); 6 on the regional (interregional) level (Murafsko-Tovtrovyi, Hnylopyatsko-Sobskyi, Zharskyi, Desniansko-Roskyi, Rivskyi, Udytskyi); 7 on the local level (Snyvodskyi, Dokhnianskyi, Liadovskyi, Nemyiskyi, Murafskyi, Rusavskyi, Silnytskyi), as a rule, small and medium rivers of the 2 nd and 3rd order, some forest areas, wetlands and forest bands. The area of the CT is 688,487 ha, which is $25.98 \%$ of the total area of the region. It has been planned to get $81,204.93$ ha of KT and CT of Eastern Podilia, which will occupy $30.64 \%$ of the total area of the region. At present, BZs are being designed, which will be installed around the KT and $\mathrm{CT}$ at the distance of up to $3 \mathrm{~km}$ and the number of RTs is being specified. We investigated that the number of RTs in the structure of the CT of the national and regional level is 60 . The total area of RT is $72,042.6$ ha, which is $2.71 \%$ of the total area of the region. Thus, the total area of the structural elements of the EN of Eastern Podilia (key, connecting and rehabilitating territories) is $884,087.53$ ha, which is $33.37 \%$ of the total area of the region (Mudrak et al., 2013).

We singled out the following groups of CT within Eastern Podilia: national, regional (that connect EN of adjacent areas) and local levels, and identified typical plant groups, which are the basis for the formation of biogeocenotic cover, which is the most similar to the natural cover according to the structure (Table 1).

\section{Prospects for further research}

There are all the necessary conditions on the territory of Eastern Podilia for the formation and implementation of the MEN as a structural unit of the PEN, which will include the abovementioned key, connecting, buffer and rehabilitating territories. Although the consolidated scheme for the formation of the MEN is already drawn up, it is not yet complete and needs to be improved.

A lot of effort should be made to single out lands of $B Z$ and $B T$, to increase the area of the nature reserves expanding existing and creating new nature reserves that would represent all the districts and regions regarding geobotanical, physical geographic, zoogeographical, hydrological, forest-typological and agroecological zoning of Eastern Podilia.

\section{Conclusions}

It was found on the basis of the conducted research that the EN of the region includes $24 \mathrm{key}, 16$ connecting and 60 rehabilitating territories. Currently, the number and area of BZs around the KT and CT are under research. The total area of the structural elements of the EN of Eastern Podilia (key, connecting and rehabilitating territories) is $884,087.53 \mathrm{ha}$, which is $33.37 \%$ of the total area of the region. It should be noted that according to the world experience, the biological balance of territories exists only if there is at least $60 \%$ of natural ecosystems. Therefore, the EN of the region still needs substantial improvement and scientifically grounded implementation.

Now it is necessary to introduce the National Target Program for the Formulation and Implementation 


\section{Table 1}

Natural nuclei and their typical groups within the main ecological corridors

\begin{tabular}{|c|c|c|c|}
\hline № & Ecological corridors & Natural nuclei & Typical groups \\
\hline 1 & 2 & 3 & 4 \\
\hline 1 & Dnistrovskyi & $\begin{array}{l}\text { Naddnistrianske } \\
\text { Liadovske } \\
\text { Dnisterske }\end{array}$ & $\begin{array}{l}\text { Forest (oak and hornbeam, pine), meadow-steppe, steppe, } \\
\text { wetland }\end{array}$ \\
\hline 2 & Buzkyi & $\begin{array}{l}\text { Sandratsko-Bereznianske } \\
\text { Tsentralno-Podilske } \\
\text { Mazurovetske } \\
\text { Seredniobuzke } \\
\text { Samchynetske } \\
\text { Buho-Sobske }\end{array}$ & $\begin{array}{l}\text { Forest, meadow, wetland } \\
\text { Forest (oak and hornbeam, oak and pine), meadow, wetland } \\
\text { Forest (pine and oak), meadow-steppe, aquatic } \\
\text { Forest, meadow, wetland, rock-steppe } \\
\text { Forest (oak and hornbeam), meadow-steppe } \\
\text { Forest (oak), meadow, rock-steppe }\end{array}$ \\
\hline 3 & Pivdenno-Podilskyi & Karmeliukovo-Podilske & $\begin{array}{l}\text { Forest (oak and hornbeam, hornbeam and oak), meadow- } \\
\text { steppe, steppe }\end{array}$ \\
\hline 4 & Murafsko-Tovtrovyi & $\begin{array}{l}\text { Harmatske } \\
\text { Murafske } \\
\text { Horiachkivsko-Kniahynske } \\
\text { Kopystyrynske }\end{array}$ & $\begin{array}{l}\text { Forest (hornbeam), meadow, wetland } \\
\text { Forest (oak, hornbeam and oak), shrub, meadow-steppe, } \\
\text { wetland } \\
\text { Forest (oak), patchy steppe } \\
\text { Forest, meadow-steppe, wetland }\end{array}$ \\
\hline 5 & Hnylopyatsko-Sobskyi & $\begin{array}{l}\text { Sestrynivske } \\
\text { Illinetsko-Dashivske } \\
\text { Buho-Sobske }\end{array}$ & $\begin{array}{l}\text { Forest (hornbeam and oak) } \\
\text { Forest (hornbeam and oak, hornbeam and ash and oak) } \\
\text { Forest (oak), meadow, rock-steppe }\end{array}$ \\
\hline 6 & Snyvodskyi & Tsentralno-Podilske & Forest (oak and hornbeam, oak and pine), meadow, wetland \\
\hline 7 & Zharskyi & Zharske & Meadow-swamp, swamp-shrub, wetland, forest \\
\hline 8 & Desniansko-Roska & Buho-Desnianske & Forest (oak and pine, alder), meadow-bog, wetland \\
\hline 9 & Rivska & $\begin{array}{l}\text { Harmatske } \\
\text { Rivske }\end{array}$ & $\begin{array}{l}\text { Forest (hornbeam), meadow, wetland } \\
\text { Forest (hornbeam and oak), meadow, wetland }\end{array}$ \\
\hline 10 & Dokhnianskyi & Ustianske & Forest (hornbeam and oak, ash and oak and hornbeam) \\
\hline 11 & Udytskyi & Krushynivske & Forest (oak, hornbeam and oak) \\
\hline 12 & Liadovskyi & Liadovske & Forest (oak and hornbeam), shrub, steppe \\
\hline 13 & Nemyiskyi & $\begin{array}{l}\text { Hrabarkivska } \\
\text { Dnisterske }\end{array}$ & $\begin{array}{l}\text { Forest (hornbeam and oak), meadow-steppe, steppe Forest } \\
\text { (oak and hornbeam, pine), meadow-steppe, steppe, wetland }\end{array}$ \\
\hline 14 & Murafskyi & Murafske & $\begin{array}{l}\text { Forest (oak, hornbeam and oak), shrub, meadow-steppe, } \\
\text { wetland }\end{array}$ \\
\hline 15 & Rusavskyi & Zhuravlivske & Forest (oak, hornbeam and oak) \\
\hline
\end{tabular}

*Note. Natural nuclei: Rivske - local level; Liadovske - regional level; Tsentralno-Podilske - national level; Dnisterske - international level.

of the National Ecological Network of Ukraine for 2009-2020, according to which the land area of the EN should reach $41.68 \%$ by $2018,50 \%$ by 2023 and $60 \%$ by 2030 (as an optimal option, two-thirds of the land should belong to the natural state) [10]. Accordingly, the area of the nature reserve fund of Eastern Podilia must constitute $5 \%$ in $2018,8.3 \%$ in $2019,10.4 \%$ in 2020 , and $15 \%$ in 2030 . Only the number of objects of the highest category of the nature reserve fund should reach 10 , i.e., $7 \%$ of the total area of the region, and now there are 5 . Therefore, the drawn-up scheme of the EN of Eastern Podilia still needs optimisation. 


\section{References}

Didukh Ya.P., Shelyag-Sosonko Yu.R. (2003) Geobotanical zoning of Ukraine and adjusting territories. Ukr. botan. journ., 60, 1. 6-17.

Marynych O.M. Physical Geography of Ukraine: textbook /O.M. Marynych, P.G. Shyshchenko. - K.: Znannia, 2005. - 511 p.

Marushevskyi H.B., Melnychuk V.P., Kostiushyn V.A. Biodiversity Conservation and Econet Development: Information Handbook; Wetlands International Black Sea Programme. - K., 2008. - 168 p.

Mudrak, O. V., Mudrak, H. V., Polishchuk, V. M. et al. (2015). Etalony pryrody Vinnychchyny [Standards of nature of Vinnytsya region]. LLC Konsol, Vinnytsia.

Mudrak O.V. Vinnytsia Region in the structure of national ecological network // Balanced (sustainable) development of Ukraine is the priority of the national politics: Proceedings of the Ukrainian scientific ecological conference (Kyiv, 26 Octo- ber 2010). - K.: Centre of ecological education and information, 2010. - 185 - $189 \mathrm{pp}$.

Mudrak O.V. (2001) Econet of Vinnytsia Region: state, problems, prospects. III Ukrainian Congress of Ecologists with international participation, 21 - 24 September. Collection of scientific articles. Volume 1. - Vinnitsa, Vinnytsia National Technical University, pp. 226-230.

Mudrak, O. V. \& Mudrak, H. V. (2013). Osoblivosti zberezhennia bioriznimanittia Podillia: teoriia I praktika [Features of biodiversity conservation in Podillia: theory and practice]. LLC Nilan, Vinnytsia (in Ukrainian).

Popovych S.Y. (2007). Natural Reserve business. - Kiev: Aristey. Environmental Legislation of Ukraine. Access mode: http:// www.rada.gov.ua - Title from the monitor.

\section{Rytų Podilija kaip visos Europos aplinkos tinklo struktūrinis padalinys}

\section{O.V. Mudrak}

Vinnitsa Tęstinio mokymo akademija, Ukraina

\section{Yu. Yu. Ovchynnykova}

Donecko nacionalinis universitetas, Ukraina

\section{G. V. Mudrak}

Vinnitsa nacionalinis universitetas, Ukraina

\section{O. M. Nagorniuk}

Vinitsa mokymo akademija, Ukraina

Remiantis moksliniais, metodiniais ir praktiniais principais bei metodais, buvo sukurta ekologinio tinklo Rytu Podilijos, sudarančios visos Europos ekologinio tinklo dali, schema. Skiriami jvairūs jo struktūriniai elementai, tokie kaip pagrindinès, jungiamosios, buferinès ir reabilituojančios teritorijos, nustatytas ju geografinis aptvarumas, plotas ir statusas. Buvo apibrežtos tipinés augalu grupès, kuriomis formuojamas pagrindiniu teritoriju (biocentrų) biogeocenetinis dangalas. Tyrimo rezultatai rodo, kad ekologini regiono tinklą sudaro 24 pagrindinès, 16 jungiamujų ir 60 reabilitacinių teritoriju. Šiuo metu paaiškinama buferiniu zonų, kurios yra nustatytos aplink pagrindines ir jungiančias teritorijas, skaičius ir plotas. Bendras Rytų Podilijos (raktų, jungiamujjų ir reabilituojančių teritorijų) struktūrinių elementų plotas yra 884 087,53 ha, tai sudaro 33,37\% viso regiono ploto. Pažymètina, kad pasaulio patirtis lemia teritoriju biologini pusiausvyrą tik tuomet, jei yra bent $60 \%$ natūralių ekosistemų. Todèl ekologiniam regiono tinklui vis dar reikalingas esminis tobulinimas ir moksliškai pagristas igyvendinimas.

Raktiniai žodžiai: kraštovaizdžio jvairovè, ekologinio tinklo struktūriniai elementai, gamtos rezervu fondas, tvarus vystymasis, Rytų Podilija. 